\title{
Examination Stress and School Administrative Policies In-Service Teachers' Motivation: It's Implication to Quality Education
}

\author{
Gemechu Abera Gobena
}

Assoc. Prof., Haramaya University, College of Education and Behavioural Sciences, Department of Psychology, Ethiopia, East Africa,gemechu46@yahoo.com

\begin{abstract}
The study was aimed to explore Examination Stress and School Administrative Policies on Inservice Teachers' Motivation: Its Implication to Quality-education. Correlational research design was employed. The target population for this study was one higher learning institution's three colleges. 358 in-service teachers were sampled out of 1078 through stratified random sampling technique. Descriptive and inferential statistics were used to analyse the quantitative data collected through close ended questionnaire. The first finding was that $61.45 \%$ of the in-service teachers were frustrated by examination stress; $57.54 \%$ of the them were influenced by school administrative policies; $70.30 \%$ of the them were not felt responsible for low results scored by their students; $79.05 \%$ of them were poorly motivated to the teaching profession; there was statistically a significant negative relationship between teachers' level of motivation and school administrative policies'. Finally, in order to sustain the quality education in the country, all concerning bodies in the study areas need to search effective mechanisms to minimize examination stress on the behalf of teachers, empower transparent school administrative policies and increase teachers' motivation through providing professional training, incentives and privilege them to different reinforcement in type and kind.
\end{abstract}

Keywords: examination stress, teachers' motivation, psychology, quality-education, stress

\section{INTRODUCTION}

There are three things to remember about education. The first one is motivation. The second one is motivation. The third one is motivation (Terrell, 1990 in Adelabu, 2005). Teachers need to know how this conceptual knowledge relates to the classroom and to their instructional role in the classroom. Teachers also need to know how to rely on this knowledge when dealing with issues that involve motivational concerns and when making instructional decisions. Teachers are important instrument in education. They are also the pivot on which the educational process hang. Teachers play a major role in the whims and caprices of the educational system. They can influence the teaching-learning outcomes either positively or negatively because they determine the quality of instructional delivery and also influence quality education when it comes to implementation of the curriculum and educational policies. They are to be considered when addressing issues such as quality assurance, quality delivery (teaching), quality context and quality learning outcomes (Onucha, 2002).

However, they are the custodians of the educational and school systems. Since teaching can be regarded as a systematic, rational and organized process of transmitting knowledge, skills, attitudes, values and what is worthwhile (education) in accordance with certain professional principles. There is a need for the services of efficient teachers (whose knowledge is bonded with innovations) in order to achieve the educational objectives. Without teachers in the school system, there will definitely be no

Citation: Gobena, G. A. (2020). Examination Stress and School Administrative Policies In-Service Teachers' Motivation: It's Implication to Quality Education. Anatolian Journal of Education, 5(1), 79-90. https://doi.org/10.29333/aje.2020.518a 
learning. Teaching makes learning take place and the teacher determines the quality of learning or instructions that will be given to learners. This is the more reason why they should be motivated properly for effectiveness and efficiency in the educational and school system (Pilot, 2007). UNESCO (2005) reemphasized that teachers' motivation is a powerful means that can improve the effectiveness of education. Its key principle is that the main actors at the forefront of education such as teachers, head teachers, and so on are responsible for improving educational performance. Teachers are essential elements in the school organization whose cost effectiveness in maintaining them accounts for over 60 percent of the total cost of education.

Teachers' motivation or empowerment should be at the forefront of government policies in order to enhance quality education and attain the goals and objectives of education (Edem, 1982). Teachers' motivation is a key to guarantee quality education, as such influences quality instruction in the educational system. Without efficient and effective teachers in the education industry, quality learning outcomes cannot be achieved. That is why teachers should be motivated properly in order to enhance quality in the educational system. As such any credible analysis of achieving quality education in the Ethiopian education system, education stakeholders should critically examine the roles played by teachers in enhancing quality in education (Saetang et al., 2010). Development of any nations depends on its educational system and teachers are expected to be the nation builders. The role of a teacher cannot be ignored in the bringing progress, prosperity and developmental process of a nation. Stability of a society is facilitated by the promotion and acceleration of growth through disciplined, academically sound and professional competent academicians. Organizational success depends on the effectiveness of the performances of the individuals who constitute the human capital (Saetang et al., 2010). This research study is therefore focused on three important components namely, examination stress, school administrative policies, and in-service teachers' motivation in general and its' implication to quality of education in particular.

\section{Research Aim}

The purpose of this study was aimed to assess the factors affecting in-service teachers' motivation and it's implication to quality-education in the area under the study. Specifically, the study was intended to:

(i) Assess the status of in- service secondary school teachers' motivations in the study area.

(ii) Identify the impact of examination stresses, and school administrative policies in-service teachers' motivation in teaching-learning processes in the study area.

(iii) Identify the extent to which secondary school teachers' motivations affect quality educations in the study area.

(iv)Pinpoint the extent to which secondary school teachers' level of motivation teaching profession in the study area.

(v) Investigate the relationship between the teachers' level motivation, examination stress, and school administrative policies in general and its implication quality of education in particular.

\section{THEORETICAL FRAMEWORK}

Arif (2003) discussed that most traditional role and objective of a culture is to protect the development of intellectualism. Competent and knowledgeable academicians are considered an important strength of any educational institution. Teaching is a very scared profession and teachers have a great role in their students' intellectual, personal and social development, thereby influencing the whole nation's development. Teaching is the supreme art of the academicians for awaking the joy in creative expression and knowledge. Only the academicians push the nations in achieving commanding heights of development through promoting intellectualism. Teachers can have influence more profound than others and give the glorious position and dignified status to the nation.

According to Kayuni \& Tambulasi (2007) lack of motivation and commitment can have a negative impact on the student's learning and most importantly it put the future of children on the stake. In 
relation to teachers' motivation level in Ethiopia, VSO (2008) indicated that large number of teachers did not feel motivated due to different factors and they would move to other profession if options are available to them. Motivation of in-service teachers is as important as the blood for sustaining the human life. Teachers who are considered to be the most precious and intellectually sound people and who can change the destiny of the nation through contribution of their thought-provoking ideas and knowledge, always being given the distinguished position in civilized societies. An issue that warrants attention in motivation research is the method and approach used to assess this construct.

\section{The School Administrative Policy Context}

Education is the compilation and product of many and varied resources. Among these, teachers stand out as a key to realizing the high standards that are increasingly emphasized in schools and school systems across the country. Despite general agreement about the importance of high-quality teachers, researchers, practitioners, policy makers, and the public have been unable to reach a consensus about what specific qualities and characteristics make a good teacher. Even more concerning is the array of policy statements regarding teacher preparation that have been set forth in the face of volumes of inconclusive and inconsistent evidence about what teacher attributes really contribute to desired educational outcomes. Policy makers are left with questions surrounding what counts as a quality teacher-information that could be valuable in guiding policies regarding whom to hire, whom to reward, and how best to distribute teachers across schools and classrooms. Answers to these questions have potentially important implications for the efficiency and equity of public education (Hammond, 2000).

\section{Examination Stress Among Teachers}

Examination in school, college and universities are a part of academic life. It has been said sometimes that student teacher's exam stress is creating mental health time bombs. It is perfectly normal to feel some stress, but too much of it will reduce effectiveness. They need to appear for examination in schools, colleges and universities or competitive examination during, which they face lot of stress and strain. The Family Doctor Association has also reported a rise in the number of teachers seeking help for exam-related stress. For examples, The British Association for Counselling and Psychotherapy has also reported increase in demand for such services. The incidence of exam anxiety has risen from $27 \%$ in 2009 to almost $40 \%$ in 2010 among all the calls received from teachers who were teaching at the three levels (schools, colleges and universities) at different times within these years (Collie, Shapka, \& Perry, 2019).

Few of the important predisposing factors for examination stress include offices and leaders' pressure for the best result of their students, deciding examinations for future growth and professional development, emotionally maturity, peer factor, poor self-image and negative thoughts. Student suicidal attempts are more common during the time of examinations or the declaration of results which made teachers too stressful for the result of their students. Due to the examination result of the students, the teachers may get depressed or develop phobia. In such cases, they may need counselling antidepressant drugs or more professional support. Examination stress is better prevented than treated. A systematic, persistent, organized, planned and regular effort from the beginning of the academic session is the best method for any in service teachers to prevent anxiety related to examination among them and their students. The best way to prevent exam stress is confidence, ensured by timely preparation for the exam. Propranolol can be of some help in reducing symptoms of examination stress. High-degree of anxiety and stress may hamper their performance (Collie, Shapka \& Perry, 2012).

\section{METHOD}

Correlational research design was employed in carrying out this study because it provides an opportunity for the researcher to predict scores and explain the relationship among variables. In 
correlational research designs, the researcher uses the correlation statistical test to describe and to measure the degree of association and relationship between two or more variables or sets of scores. In this design, the researcher does not attempt to control or manipulate the variables as in an experiment; instead, he tried to relate, using the correlation statistic, two or more scores for each variables under the study (Creswell, 2012).

\section{Participants}

The target population for this study consisted of one higher learning institution, Haramaya University's three colleges- College of Natural \& Computational Sciences (CNCS), College of Social Sciences \& Humanities (CSSH), and College of Education \& Behavioural Sciences (CEBS) - inservice secondary school teachers. 358 in-service teachers were sampled out of 1078. $78(21.79 \%)$ teachers were female whereas the rest $280(78.21 \%)$ of them were male. Then a stratified random sampling technique was employed because firstly, there were different subdivisions in the targeted population which are important to be considered. Secondly, there were also variations in population sizes of different strata in this case sex, age, department and colleges. Moreover, the researcher used systematic random sampling to take the sample that has already been identified through stratification.

\section{Instruments}

The researcher employed two types of data gathering instruments; questionnaires and document review to collect both quantitative and qualitative data respectively. To make the interpretation descriptively easier, the researcher used descriptive statistics (percentages, frequency, means, and standard deviation) to describe the characteristics of the respondents. Furthermore, inferential statistics (bivariate correlation, independent chi-square test, one way ANOVA and stepwise multiple regression) were used to show the degree of strength or relationship, associations among the variables, mean differences and average relationship to predict or estimate the most likely value of those variables respectively. This result was statistically significant at $\alpha=0.05$ level.

\section{FINDINGS}

This chapter has two parts: the first part deals with the characteristics of the respondents; and the second part presents the analysis and interpretation of the main idea. To this end, both quantitative and qualitative data were gathered through questionnaire and document reviews. The data gathered through document reviews were supposed to supplement the quantitative data. Questionnaire was distributed to 373 respondents out of which 358 (95.98\%) copies were returned back. The respective quantitative data were analysed quantitatively using frequency, percentage, chi-square tests and Spearman rank correlation. On the other hand, the triangulations were made to check the consistencies and variations of the result obtained from the two instruments. The analysed data were compiled and organized in a way that suits interpretations of the results in addressing the research questions. In this way, 10 tables were constructed in categorizing the objectives of the study in thematic groups to the extent to which the current trends and practices of in service teachers' level of motivations and its implication to quality of education in general and the study areas in particular. The data obtained from respondents were analysed using the Statistical Package for the Social Sciences (SPSS version 16).

Table1

Respondents' Demographic Characteristics by Sex

\begin{tabular}{lll}
\hline Sex & Frequency & Percent \\
\hline Male & 280 & 78.21 \\
Female & 78 & 21.79 \\
\hline Total & 358 & 100.0
\end{tabular}

As the table1 shows, the majorities $280(78.21 \%)$ of the total sampled in-service secondary school teachers were males whereas the rest $78(21.79 \%)$ of them were females. From this, one can suggest 
that there was a big gap of sex disparities among secondary school teachers in these selected samples under the study.

Table2

Respondents' Characteristics by Residence

\begin{tabular}{lll}
\hline Respondents' Residence & Frequency & Percent \\
\hline Rural & 187 & 52.23 \\
Urban & 171 & 47.77 \\
\hline Total & 358 & 100.0
\end{tabular}

As it can be seen from table2, the majorities 187 (52.23\%) of the respondents were teaching in rural areas whereas $171(47.77 \%)$ of them were teaching in urban areas. From these data, one can identify that the school development in Ethiopia has been changing dramatically from urban cantered of establishment to rural areas where most Ethiopian have been leaving.

Table 3

Respondents' Characteristics by College

\begin{tabular}{lll}
\hline Colleges & Frequency & Percent \\
\hline College of Natural and Computational Sciences (CNCS) & 218 & 60.89 \\
College of Social Sciences and Humanities (CSSH) & 77 & 21.51 \\
College of Education and Behavioural Sciences (CEBS) & 63 & 17.60 \\
\hline Total & 358 & 100.0
\end{tabular}

From the table 3 shown, it can be understood that the majorities $218(60.89 \%)$ of the respondents were selected from CNCS; 77 (21.51\%) of them were selected from CSSH and the rest $63(17.60 \%)$ of them were selected from CEBS. This seemed that the 61: 39 enrolment ratios were seemed to be implemented as per the national curriculum of the country which was natural sciences to social sciences ratio were 70:30, respectively.

\section{Analysis of Examination Stress, and School Administrative Policies on In-Service Teachers'} Motivation

These parts of the data analyses were mainly dealing with those variables that have been contributing to demotivating those subjects under the study. These variables include in-service teachers' attitudes towards teaching profession, examination stress, and school administrative policies. Therefore, the researcher tried to organize, present, analyse and interpret both quantitative and qualitative data that the researcher collected through questionnaire and document review respectively as follows.

Table4

The Impact of Examination Stress on Teachers' Level of Motivation

\begin{tabular}{|c|c|c|c|c|c|c|c|}
\hline \multirow[t]{2}{*}{ No Items } & \multicolumn{4}{|c|}{ Descriptive Analysis } & \multicolumn{3}{|c|}{ Inferential Analysis } \\
\hline & No & $\%$ & Yes & $\%$ & $\mathrm{df}$ & $\chi^{2}$ & Sig. \\
\hline 1. Do you think that examination affects your teaching? & 138 & 38.55 & 220 & 61.45 & 1 & 3.19 & 0.08 \\
\hline $\begin{array}{l}\text { 2. Are you accountable to the principal for the low results of } \\
\text { your classes? }\end{array}$ & 100 & 27.93 & 258 & 72.07 & 1 & 67.49 & 0.00 \\
\hline 3. Are you blamed for low results? & 143 & 39.94 & 215 & 60.06 & 1 & 0.95 & 0.33 \\
\hline 4. Do you think that you are responsible for their low result? & 68 & 19.00 & 290 & 81.00 & 1 & 103.40 & 0.00 \\
\hline $\begin{array}{l}\text { Do you think that students should be responsible for their } \\
\text { low result? }\end{array}$ & 78 & 21.79 & 280 & 78.21 & 1 & 81.50 & 0.00 \\
\hline $\begin{array}{l}\text { Do you think that you are given incentives accord-ing to } \\
\text { your abilities? }\end{array}$ & 135 & 25.14 & 223 & 74.86 & 1 & 3.59 & 0.06 \\
\hline $\begin{array}{l}\text { Do you think teachers should be held respons-ible for low } \\
\text { results? }\end{array}$ & 90 & 29.70 & 268 & 70.30 & 1 & 49.93 & 0.00 \\
\hline $\begin{array}{l}\text { Do you think that teachers should be rewarded on showing } \\
\text { good results? }\end{array}$ & 64 & 17.88 & 294 & 82.12 & 1 & 112.95 & 0.00 \\
\hline
\end{tabular}


As it can be identified from table4 item1, the majorities $220(61.45 \%)$ of the respondents were responded that they thought that they were affected by examination stress in teaching-learning processes in their respected schools, but nearly half $138(38.55 \%)$ of them were responded that they thought that they were not affected by examination stress during teaching-learning processes in their respected schools. Furthermore, from item by item analysis of chi-square test, it was so easy to conclude that there was no statistically significant association between teachers' level of motivation and examination stress in teaching learning processes, $\chi^{2}(1, n=358)=3.17, p>0.05$, one tailed. This idea was not supported by the data obtained from document reviews.

In the same fashion, table4 item 2 given above was indicated that the majorities $258(72.07 \%)$ of the respondents were responded that they thought that they were very much confident and were accountable to the principals for the low result scored by their students in the classes in teachinglearning processes, but the rest $100(27.93 \%)$ of them were responded that they thought that they were not very much confident and were not accountable to the principals for the low result scored by their students in the classes in teaching-learning processes. Furthermore, from item by item analysis of chisquare test, it was concluded that there was statistically a significant association between teachers who were very much confident and were accountable to the principals for the low result scored by their students in the classes and teachers' level of motivation, $\chi^{2}(1, n=358)=67.49, p<0.05$, one tailed. This idea was fully supported by the data obtained from document reviews.

From the same table4 item3, almost half 215 (60.06\%) of the respondents were responded that they thought that they were not very much blamed for low result scored by their students, but nearly 143 (39.94\%) of them responded that they thought that they were very much blamed for low results scored by their students in teaching learning processes in their respected schools. Besides, the chi-square test analysis was identified that there was no statistically significant association between teachers who were very much blamed for low result scored by their students and teachers' level of motivation in teaching-learning processes, $\chi^{2}(1, \mathrm{n}=358)=0.94, \mathrm{p}>0.05$, one tailed. This idea was fully supported by document reviews.

From the same table4 item4, the majorities 290 (81.00\%) of the respondents were responded that they thought that they were felt very much responsible for the low results scored by their students and teachers' level of motivation in teaching-learning processes, but only $68(19.00 \%)$ of them were responded that they thought that they were not very much felt responsible for low results scored by their students in their respected schools. Furthermore, from item by item analysis of chi-square test, it was identified that there was statistically a significant association between teachers who were very much felt responsible for low results scored by their students and their level of motivation in their respected schools, $\chi^{2}(1, \mathrm{n}=358)=103.40, \mathrm{p}<0.05$, one tailed. This idea was fully supported by the data obtained from document reviews.

As it was indicated in the same table4 given above item5, the majorities $280(78.21 \%)$ of the respondents were responded that their students should feel responsible for the low results scored by them in teaching learning processes, but only 77 (21.79\%) of them were responded that their students should not feel responsible for the low results scored by them. Furthermore, from item by item analysis of chi-square test, it was pinpointed that there was statistically a significant association between teachers who were very much confident that they their students should feel responsible for the low results scored by them and teachers' level of motivation in teaching-learning processes, $\chi^{2}(1, \mathrm{n}=358)$ $=87.50, \mathrm{p}<0.05$, one tailed.

This idea was fully supported by document reviews. In the same fashion table4 item6 was indicated that the majorities $223(74.86 \%$ ) of the respondents were responded that they thought that they were given different incentives in kinds and in types according to their performances and abilities in teaching-learning processes, but the rest $135(25.14 \%)$ of them were responded that they were not 
given different incentives in kinds and in types according to their performances and abilities in teaching-learning processes. Furthermore, from item by item analysis of chi-square test, it was concluded that there was no statistically significant association between teachers who were given different incentives in kinds and in types as per their performances and abilities and teachers' level of motivation in teaching learning processes, $\chi^{2}(1, \mathrm{n}=358)=3.59, \mathrm{p}>0.05$, one tailed. This idea was fully supported by the data obtained from document reviews.

As it can be understood from the same table4 item7 given above, the majorities $268(70.30 \%)$ of the respondents were responded that teachers should be held responsible for low results scored by their students in teaching-learning processes whereas the rest $90(29.70 \%)$ of them were responded that teachers should not be held responsible for low results scored by their students in teaching-learning processes. Furthermore, from item by item analysis of chi-square test, it was found that there was statistically a significant association between teachers who should be held responsible for low results scored by their students and their level of motivation in teaching-learning processes, $\chi^{2}(1, n=358)=$ $49.93, \mathrm{p}<0.05$, one tailed. This idea was fully supported by document reviews.

In the same fashion table4 item8 was indicated that the majorities $294(82.12 \%)$ of the respondents were responded that they should be rewarded for their good results that they have accomplished in teaching-learning processes, but only $64(17.88 \%)$ of them were responded that they thought that they should not be rewarded for their good results that they were not accomplished in teaching-learning processes. Furthermore, from item by item analysis of chi-square test, it was found that there was statistically a significant association between teachers who should be rewarded for their good results that they have accomplished and their level of motivation in teaching-learning processes, $\chi^{2}(1, \mathrm{n}=$ $358)=112.95, \mathrm{p}<0.05$, one tailed. This idea was fully supported by document reviews that teachers who performed well should be encouraged by different incentives.

In support of these analyses, Soleme (2014) stated that lack of incentives in kind and in type will result in low teacher motivation which in turn leads to negative educational outcomes which again in turn resulted in poor quality of education. In the same study, it was found that low motivation results in absenteeism, underutilization of class time, professional misconduct, and reliance on traditional teaching practices, poor preparation, and secondary income-generating activities that distract from teaching duties. Similarly, a study conducted by VSO (2008) indicated that teacher motivation in Ethiopia, Zambia, Papua New Guinea, and Malawi found that low motivation results in high attrition rates, constant turnover, lack of confidence, varying levels of professional commitment, and a feeling of helplessness to either improve student outcomes or teachers 'own situations. Furthermore, theoretical literature on teacher motivation in developing countries is sparse, but certain psychological theories offer relevant applications for the developing country context.

For instance, Maslow's (1943) hierarchy of needs proposes that individuals must fulfil their lowerorder needs (basic needs such as water and housing, safety, belonging, and esteem) before being motivated to fulfil the higher-order need for self-actualization. In the context of teaching, selfactualization can be understood as personal achievement, a key component of teacher motivation. As basic needs often go neglected in the developing world, Maslow's theory is pertinent to an investigation of teacher motivation in developing countries. While the fulfilment of basic needs is important to lay the foundation for teachers to desire to improve their professional behaviour and personal achievement, satisfaction of basic needs in and of itself functions as a mere extrinsic, or external, incentive. 
Table 6

In- Service Teachers' Level of Motivation

\begin{tabular}{lllll}
\hline Rating Scales & Frequency & Percent & Percent & Cumulative Percent \\
\hline Very poor & 166 & 46.37 & 47.37 & 46.37 \\
\hline Poor & 117 & 32.68 & 32.68 & 79.05 \\
\hline Medium & 28 & 7.82 & 7.82 & 86.87 \\
\hline High & 33 & 9.22 & 9.22 & 96.09 \\
\hline Very High & 14 & 3.91 & 3.91 & 100.0 \\
\hline Total & 358 & 100.00 & 100.00 & \\
\hline
\end{tabular}

As it has been indicated from the table6, the cumulative frequencies $283(79.05 \%)$ of the respondents were responded that they were either poorly or very poorly motivated to the profession of teaching; 28 $(7.82 \%)$ of them were responded that they were motivated moderately to the profession of teaching whereas the rest $47(13.23 \%)$ of them were responded that they were either highly or very highly motivated to the profession of teaching. Moreover, the data obtained from document reviews were indicating that they were not as such motivated to the profession of teaching. Lack of portfolio practices and lack of conducting action research were one of the main indicators that teachers have not yet been motivated to the profession of teaching.

In the support of these analyses, Welmond (2002); and Lauwerier (2013) indicated that poor or very poor motivation of teachers in this context compromises the quality of their activity and has led to institutional instability in many countries, with repeated strikes and wasted school years. For instance, a study carried out in South Africa also revealed the negative impact of strikes on learning, particularly among the most deprived pupils (Wills, 2014). Finally, Buckler and Gafar (2013) conducted research on teacher morale over a four-year period in a rural region of Ghana. One of its findings was that training partly improved their morale, in particular by giving them a sense of professional identity as teachers. On the other hand, teachers who lack the ability needed to improve the attainment of their pupils are affected by this shortcoming. Thus, it can be indicated that teachers' motivation affects quality education delivery.

Table 7

Spearman Correlation Matrices between Teachers' Level of Motivation and Administrative Policies

\begin{tabular}{lllllll}
\hline Variables & Teachers' Level of Motivation & \multicolumn{7}{l}{ Administrative Policies' -Variables } \\
\cline { 2 - 6 } & & 2 & 3 & 4 & 5 \\
\hline $\begin{array}{l}\text { Teachers 'Level } \\
\text { of Motivation }\end{array}$ & 1.00 & $-0.150^{* *}$ & $-0.164^{* *}$ & $-0.131^{* *}$ & $-0.177^{* *}$ & $-0.399^{* *}$ \\
\hline
\end{tabular}

***Correlation is significant at the 0.01 level (2-tailed).

* Correlation is significant at the 0.05 level (2-tailed).

Where 1= Participation in decision making, 2= Communicating policies and procedures, $3=$ Fair and transparent placement policies, $4=$ career development opportunities, and $5=$ Accountability systems for both teaching staffs and students.

As it can be seen from table7, there was statistically a significant weak negative relationship between teachers' level of motivation and schools' administrative policies' variables particularly participation in decision making, $\rho(356)=-0.150^{* *}, p<0.05$. Meanwhile, it was found that there was statistically a significant weak negative relationship among teachers' level of motivation versus communicating policies \& procedures; teachers' level of motivation versus fair \& transparent placement policies; teachers level of motivation versus career development opportunities; teachers' level of motivation 
versus accountability systems for both teaching staffs \& students respectively, $\rho(356)=-0.150^{* * *}, \rho$ $(356)=-0.164^{* *}, \rho(356)=-0.131^{* *}, \rho(356)=-0.177^{* *}$; , and $\rho(356)=-0.399^{* * *}, \mathrm{p}<0.05$, two tailed.

In opposing to this finding, the previous study by Leithwood, Steinbach and Jantziy (2018) found out that teachers and administrators made approximately the same proportion of comments about government intentions for accountability policies: 37 of 48 teachers made 109 such comments as compared with 11 of 15 administrators who made 30 such comments. Teachers averaged 2.9 such comments per person as compared with 2.7 for administrators. However, Hülya et.al. (2018) demonstrated there is a weak correlation $(r=0.159, p=0.15)$ between teachers' level of motivation $(\mathrm{M}=1.99, \mathrm{SD}=0.75)$ and administrative policies $(\mathrm{M}=7.33, \mathrm{SD}=0.67)$ and the correlation between the two scores is not significant. This means that the scores obtained from the two instruments cannot be related to each other.

Table 8

Regression Analysis

\begin{tabular}{|c|c|c|c|c|c|c|c|c|}
\hline \multirow{2}{*}{\multicolumn{2}{|c|}{ Model }} & \multirow[t]{2}{*}{$\mathrm{R}$} & \multirow[t]{2}{*}{$\mathrm{R}^{2}$} & \multicolumn{2}{|l|}{ USC } & \multirow{2}{*}{$\begin{array}{l}\text { SC } \\
\text { Beta }\end{array}$} & \multirow[t]{2}{*}{$\mathrm{t}$} & \multirow[t]{2}{*}{ Sig. } \\
\hline & & & & $\mathrm{B}$ & SE & & & \\
\hline & (Constant) & & & 5.98 & 0.40 & & 11.854 & 0.00 \\
\hline \multirow{2}{*}{2} & Examination stress & 0.87 & 0.7569 & -1.67 & 0.06 & -0.29 & -3.75 & 0.00 \\
\hline & Teachers' Level of Motivation & & & -1.77 & 0.05 & -0.17 & -2.52 & 0.012 \\
\hline
\end{tabular}

a. Dependent Variable: quality educations

As the table8 reveals, the regression analysis on the extent to examination stress and teachers' level of motivations affect quality education as measured by regression correlation coefficient $(0.87)$ was contributing $75.69 \%$ to deteriorating of quality education as measured by the Stepwise Regression Analysis Coefficient $\left(\mathrm{R}^{2}\right) * 100$ or this result means that $75.69 \%$ of the variation in the dependent variable is accounted for by the variations in the independent variables whereas the rest unexplained variables $\left(1-\mathrm{R}^{2}\right) * 100$ was contributing $24.31 \%$ to deteriorating quality of education. This means that the rest of the variation $24.31 \%$ is unexplained. The t-value is significant for the two variables namely examination stress and teacher' level of motivation as mentioned in the table8.

Moreover, the accompanying computer printout shows a regression equation that predicts the extent to which examination stress affect quality education were by the two statistically significant independent variables namely were examination stress $\left(\mathrm{x}_{1}\right)$ and teacher' level of motivation $\left(\mathrm{x}_{2}\right)$. Therefore, the simple regression equation for dependent variable- quality of education (Y) could be expressed in terms of these statistically significant independent variables that have already been mentioned was $\mathbf{Y}=$ $5.98-1.67 x_{1}-1.77 x_{2}$ where 5.98 is constant. The negative slopes of the two variables respectively were $(-1.67$ and -1.77$)$ which used to indicate that per a unit increase of the independent variables would tend to respectively decreases $(-1.67$ and -1.78$)$ the quality of education.

In supporting this finding, Polly (2009), like others, in her study on the influence of motivation and examination stress on teacher's performance in Rwanda, noted that a feeling of self-worth and recognition by a worker enhance their desires to give much to the organization. Moreover, Noor (2009) stated that focusing on the relationship between teachers' level of motivation and level of examination stress in national examinations, a pool of factors, working in an interplay, were found to influence academic results. These factors were basically teacher related and bordered on motivational aspect in service training for gaining more skills and knowledge, better remuneration, material rewards and suitable working conditions can reduce examination stress. Research has found that, apart from the external factors like unmotivated teachers, heavy workload, and poor working conditions and administration policies have correlations with stress ((Klassen \& Chiu, 2010). 


\section{CONCLUSION}

The majority $(60.89 \%)$ of the respondents were selected from College of Natural \& Computational Sciences (CNCS) whereas the rest $39.11 \%$ of them were respectively from College of Social Sciences \& Humanities (CSSH), and from College of Education \& Behavioural Sciences (CEBS). This seemed that 61: 39 enrolment ratios were roughly implemented as per the national curriculum of the country which was 70: 30 natural sciences to social sciences ratio respectively. It was concluded that $79.05 \%$ of the teachers were either poorly or very poorly motivated to the profession of teaching. Lack of portfolio practices and lack of conducting action research were one of the main indicators that most inservice teachers have not been yet motivated to the profession of teaching.

\section{Examination Stress}

$61.45 \%$ of the teachers were affected by examination stress in teaching-learning processes. However, it was concluded that there was no statistically significant association between teachers who were affected by examination stress and their level of motivation in their respected schools. Moreover, $72.07 \%$ of the teachers were very much blamed for the low result scored by their students in teaching learning processes. On the other hand, $60.06 \%$ of the teachers were felt very much responsible for the low results scored by their students in teaching-learning. From this analysis, one can conclude that teachers were demotivated by feeling responsible and scapegoat for the low score scored by their students because there were no merit-based incentives to encourage them and discourage otherwise in the school systems. $81.00 \%$ of the teachers were felt responsible for the low results scored by their students in teaching-learning processes. $74.86 \%$ of the in-service teachers were not given different incentives in kinds and in types for their performances and abilities in teaching-learning processes. $70.30 \%$ of the teachers should be held responsible for low results scored by their students in teachinglearning processes. On the other hand, $82.12 \%$ of the in- service teachers were expected to be rewarded for their good results that they have accomplished in teaching-learning processes.

\section{School Administration Policies}

$57.54 \%$ of the teachers were responded that their school administrative policies did not have a transparent performance appraisal system. $79.61 \%$ of the teachers were not appreciated by their heads in participating in decision making in their respected school. $69.27 \%$ of the teachers were felt that their school administrative policies and procedures were not best communicating them in decision making in school. $58.10 \%$ of the teachers were responded that their school administration was not as such the best in communicating transparent placement policies and procedures in their respected schools. On the other hand, $72.26 \%$ of the teachers were responded that most school administrative policies did not favour them in finding career development opportunities within or outside of the country. Finally, $79.61 \%$ of the respondents were responded that there was no effective accountability systems exist on (both academic staff \& students) in teaching-learning processes.

Therefore, it can be concluded that there was statistically significant association between teachers' level motivation and school administrative policies systems in teaching-learning processes. From Spearman correlation analysis, it can be concluded that there was a very weak negative relationship between teachers' level of motivation and schools' administrative policies' variables (teachers' participation in decision making; administrative communicating policies with teachers, fair and transparent placement policies, teachers' career development opportunities, and accountability system for both teaching staffs and students) which was found to be statistically significant.

Examination stress and teacher' level of motivation was contributing $75.69 \%$ to deteriorating of quality education as measured by the Stepwise Regression Analysis Coefficient $\left(\mathrm{R}^{2}\right) * 100 \%$. This result indicates that $75.69 \%$ of the variation in the dependent variable is accounted for by the variations in the independent variables whereas the rest unexplained variables $\left(1-\mathrm{R}^{2}\right) * 100 \%$ was contributing 
$24.31 \%$ to deteriorating quality of education. This means that the rest of the variation $24.31 \%$ is unexplained.

\section{RECOMMENDATIONS}

In order to sustain the quality of education to better use of teachers' knowledge and skills and to improve student achievement, the following recommendations were forwarded to all concerning bodies in the study areas. School-leaders, policy makers and curriculum designers should equally provide responsibility of academic achievement to students rather than to teachers to increase teachers' level of motivation. Therefore, examination stress should be the main determinant factors involved in teachers' workload stress that are outside of the educational realm and are determined largely by thinking related to dealing with complex issues. In other words, the matters that emerged as stressful should be the issues of examination stress to teachers' level of motivation. Similarly, in looking at problems in society, it is not obvious that schools should have the primary responsibility for students' achievement or failure; rather it seems that there is no other institution that might take responsibility for these complex matters.

Education stakeholders should advocate on the behalf of teachers with ministries of education to improve communications throughout the education system so that teachers at all levels are aware of education policy, understand their role in implementing it and can make their views heard. Moreover, teachers must be given training on strategic management so that they can play a larger role in schoollevel decision-making, facilitating quality circles among teachers, facilitating school-based management to allow teachers more input into school-level decisions. This in turn can motivate teachers to improve their performance and effectiveness in teaching and active participation and involvement of teachers and headmasters in decision-making with clearly defined roles and responsibilities. Therefore, teachers and administrators should routinely develop their own knowledge and skills model for students so that learning is important and useful.

Finally, large proportions of teachers are poorly motivated because their basic needs for food, housing and security are not met. Consequently, in accordance with Maslow's Hierarchy of Needs theory, efforts to improve educational quality, which depend crucially on higher order needs, are unlikely to succeed unless these basic needs are adequately satisfied. While these inevitably vary from one region to another, recommendations in the following four key areas are identified as top priorities in virtually all the reports: better incentives to teachers, improved conditions of service, attractive career structures, and increased teacher and school accountability.

\section{IMPLICATIONS}

Teachers are one of the mainstays of quality education, as extensive research and many recommendations have demonstrated. Yet the very concept of quality requires careful thought. More specifically- and over and above quantifiable school attainment levels - it is vital to determine whether teachers have the wherewithal to achieve education that is relevant in corresponding to the expectations and needs of students and their community to improve learning attainment and thus contribute to national development. Students should clearly identify that learning during the school year makes it easier for teachers to apply what they learn immediately within their work places so that students benefit immediately.

\section{REFERENCES}

Adelabum M. A. (2005). Teacher motivation and incentives in Nigeria. Its meaning and measure. Review of Educational Research, 68, 202-248.

Arif, H. M. (2003). Human development and learning. Journal of Educational Research, 81, 109-115. 
Bennell, P., \& Akyeampong, K. (2007). Teachers motivation in sub-Saharan Africa and South Asia. Department of International Development Educational papers.

Collie, R. J., Shapka, J. D., \& Perry, N. E. (2019). School climate and social-emotional learning: Predicting teacher stress, job satisfaction, and teaching efficacy. $J$ of Edu Psyc, 121(4), 118-129.

Creswell, J. W. (2012). Educational research: Planning, conducting and evaluating quantitative and qualitative research. Boston: Pearson Education.

Edem, D.A. (1982). Introduction to educational administration. Ibadan: Spectrum.

Gedefaw, K. (2012). Job satisfaction of secondary school teachers in Ethiopia (Unpublished doctoral dissertation). University of South Africa.

Hülya, İ., Asli, A., Sibel, A., Gizem, B., Tuncay, K., \& Temel, S. (2018). The between occupational stress and teacher self-efficacy: A study with EFL instructors. Anadolu J of Edu Sci Int, 8(1), 126-150.

Kayuni, H., \& Tambulsai, R. (2007). Teacher turnover in Malawi's Ministry of Education: Realities and challenges. International Education Journal, 8(1), 89-99.

Klassen, R. M., \& Chiu, M. M. (2010). Effects on teachers' self-efficacy and job satisfaction: Teacher gender, years of experience, and job stress. Journal of Educational Psychology, 102(3), 741-756.

Lauwerier, T. (2013). The influence of the world bank on national policies for basic education in French-speaking West Africa. Geneva: FAPSE, University of Geneva.

Maslow, A. H. (1943). A theory of human motivation. Psychological Review, 50, 379-396.

Onocha, C. O. (2002). Quality assurance in teacher education. Teacher education in Nigeria: past, present and future proceedings of the first Teachers' summit, February 2002. Kaduna: National Teachers' Institute.

Pilot, A. (2007). The teacher as a crucial factor in curriculum innovation, the case of Utrecht University. Retrieved from www.diz.ethz.ch/veranstaltungen/freuhereveranstaltungen/conference/keynote/pilot_paper.pdf+the+tea cher.

Polly, D. (2009). Factors influencing employee performance in local authority in Oyugis Town council; A survey of the level of public service delivery.

Selome, A. (2014). Factors affecting teachers' motivation in some selected primary schools of Addis Ababa city Administration. MA - Thesis.

UNESCO. (2006). Teacher motivation, compensation and working conditions. International Institute for Educational Planning (IIFEP).

Welmond, M. (2002). Globalization viewed from the periphery: The dynamics of teacher identity in the Republic of Benin. Comparative Education Review, 46, 37-65.

Wills, G. (2014). The effects of teacher strike activity on student learning in South African primary schools. Johannesburg: Economic Research Southern Africa. 